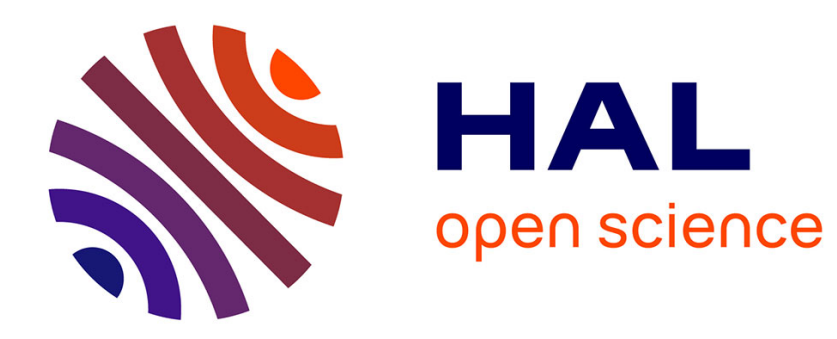

\title{
Wormy Collaborations in Practices of Soil Construction
}

Germain Meulemans

\section{To cite this version:}

Germain Meulemans. Wormy Collaborations in Practices of Soil Construction. Theory, Culture and Society, 2020, 37 (1), pp.93-112. 10.1177/0263276419851857 . hal-02882907

\section{HAL Id: hal-02882907 https://hal.science/hal-02882907}

Submitted on 28 Jun 2020

HAL is a multi-disciplinary open access archive for the deposit and dissemination of scientific research documents, whether they are published or not. The documents may come from teaching and research institutions in France or abroad, or from public or private research centers.
L'archive ouverte pluridisciplinaire HAL, est destinée au dépôt et à la diffusion de documents scientifiques de niveau recherche, publiés ou non, émanant des établissements d'enseignement et de recherche français ou étrangers, des laboratoires publics ou privés. 


\title{
Wormy Collaborations in Practices of Soil Construction
}

\author{
Germain Meulemans
}

This is the Accepted Manuscript of a journal article published in Theory, Culture \& Society, 37(1), 93-112. Article first published online: July 7, 2019; Issue published: January 1, 2020. DOI : https://doi.org/10.1177/0263276419851857

\begin{abstract}
This paper studies the capture of organisms and materials in soil construction - a branch of ecological engineering dedicated to making soil in order to compensate for soil degradation. This approach takes all organisms to be 'ecosystem engineers', and often refers to earthworms as 'collaborators' in making soil. I examine the claim that such convocation of worms amounts to a redistribution of agency and the underlying assumption that form-taking is the shaping of raw matter according to pre-existing forms. Drawing on processual anthropology, I question the distinction between living and material components of soils, and between growing and making. I elaborate on soil scientists' description of soil growth as pedogenesis in order to propose a view in which soil materials, along with organisms, participate in soil's transformative and generative fluxes. I envisage the process as a concrescence, an experimentation that brings humans, worms, and soil materials together in new ways.
\end{abstract}

\section{Keywords}

Anthropology, earthworms, concrescence, pedogenesis, materialism, living soil, collaboration, making. 


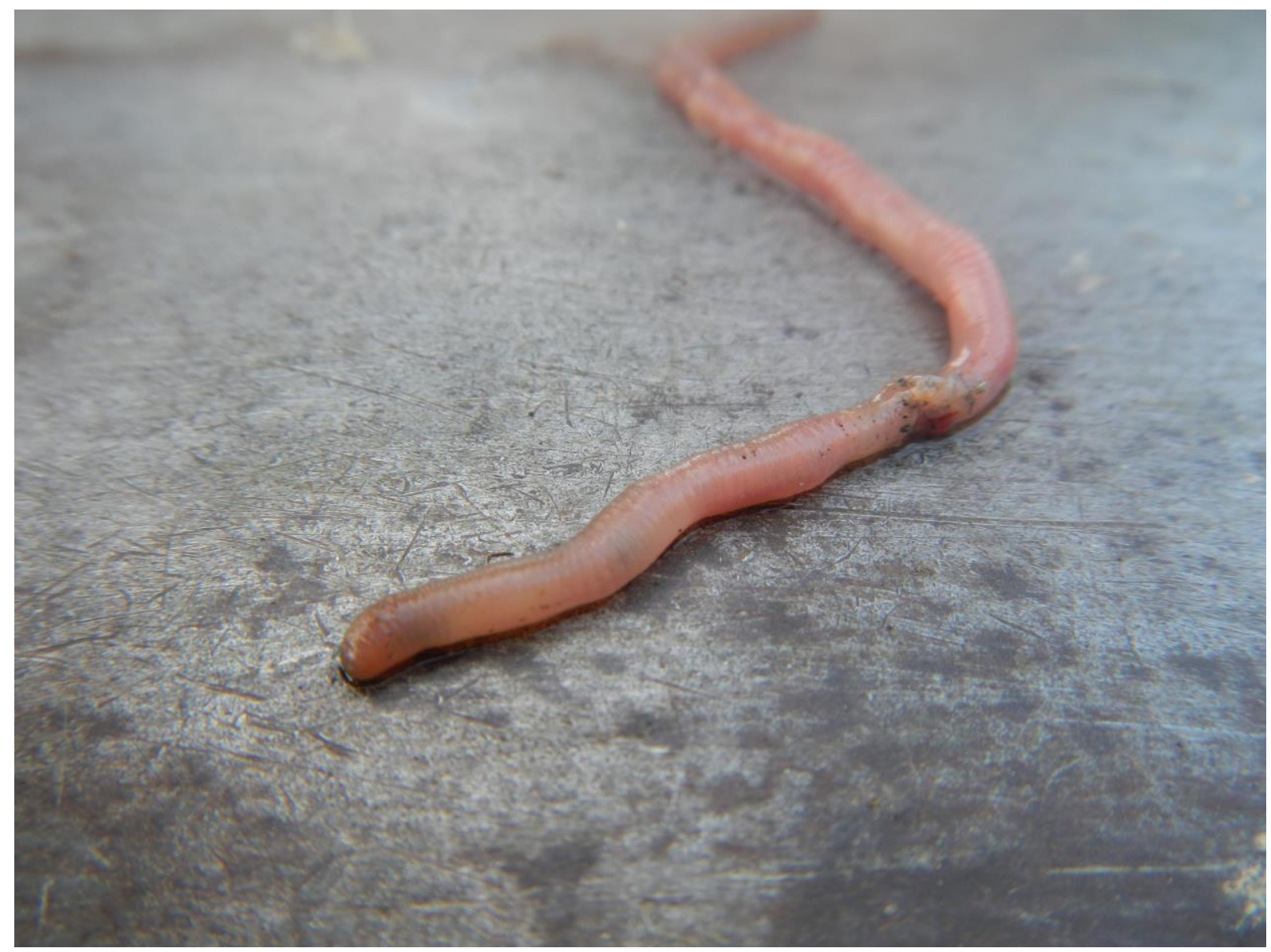

Figure 1: One of the soil scientist's 'indefatigable collaborators' (photo by author)

Long regarded as a mere background to human history and mastery, soils have recently attracted wider attention in anthropology and social theory as things conducive to responsive or caring relations. Scholars in the humanities - and more particularly in feminist Science and Technology Studies - have taken seriously the idea that soil is not just a material substrate in which plants grow and feed, but a living compound, woven in and through the lives of the organisms that live in and with it - including humans (Engel-Di Mauro, 2014; Lyons, 2016; Puig de la Bellacasa, 2017). Such works have questioned what it means to live with living soils - which can also be damaged or toxic soils (Ureta, 2018) inherited from centuries of exploitation of earthly ecologies (Tsing, 2015) - as they come to be regarded as an 'infrastructure of bios' (Puig de la Bellacasa, 2014) that requires attention and care. 
In this article, I want to bring an anthropological perspective on making, materials and activity into this debate and address what it means to live and work with soils from a maker's point of view. More specifically, I shall critically inhabit the claim of soil makers, namely, that making good soil entails a 'collaboration' with soil organisms. In Europe and North-America, practices that focus on making or growing soil can be located in permaculture, organic farming, gardening, or soil ecology. Often, practitioners from these fields refer to the need to 'collaborate' with soil organisms, conferring on them a role as co-makers that is absent from mainstream forms of agriculture. Among the myriad soil-dwelling organisms, worms have beyond doubt attracted the greatest attention in these fields. At a time when soils are threatened by urban sprawl, intensive agriculture, and global warming, earthworms are regularly described as allies in making or restoring healthy soils.

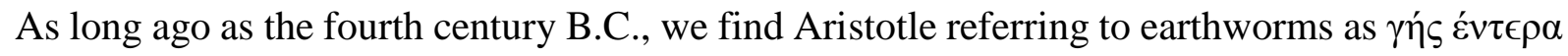
(ges entera) or the earth's intestines. However, though it would be tempting to regard the great philosopher as a precursor to contemporary understandings of the role of worms' guts in making soils, closer examination reveals that Aristotle's metaphor is simply based on a visual resemblance between worms and guts (Rota, 2011). It seems that the benefits that earthworms and their guts deliver to the soil were not properly appreciated until well into the eighteenth century. The idea of feeding worms to improve the soil started to appear in gardening books in the nineteenth century and has been increasingly publicised in Europe and North America since the 1980s, along with the growing popularity of organic gardening (Stewart, 2004). Methods of cultivation relying on the work of worms and soil fauna are now becoming popular even within more mainstream forms of agriculture, and no-till cultivation techniques that rely on soil organisms are featuring widely in agendas for agronomic research (Puig de la Bellacasa, 2017). Often, gardening books - and also more and more agricultural manuals - emphasise not only the efficiency of relying on these 'indefatigable collaborators' (Lavelle, in Bouché, 2014: 9, my 
trans.), but also the sense of coherence with natural cycles, and the mutual benefits to humans and their non-human counterparts, that such practices imply. As non-fiction writer Amy Stewart puts it in a 2004 best-selling book on gardening with earthworms:

This, then, is what is still remarkable to me about growing my own vegetables: I feed the worms in the form of kitchen scraps going into my worm bin, and in the form of manure and dead leaves that I spread around the garden as mulch. And in return, the worms feed me. (Stewart, 2004: 108)

Until recently, and with the exception of their benefits for plants, the soil sciences were little interested in soil organisms and their role in the growth of soils. Even though research in oligochaetology - the study of earthworms - developed throughout the twentieth century, its practitioners identified mostly with zoology. Since its inception in the work of the Russian geologist Vasily Dokuchaev, pedology had understood soils to be products of four factors that act over time: the climate, organisms, relief, and parent material. The organisms that Dokuchaev had in mind, however, were almost exclusively plants, and the subsequent consideration of the role of organisms in soil formation has been limited to 'a flora focus, with animals considered as afterthoughts, as minor components, or not at all' (Johnson and Schaetzl, 2015: 177). For Johnson and Schaetzl, the success of this factorial approach lies in its strong orientation towards application. In a context of rapidly developing productivist agriculture, it provided a theoretical basis for classifying and mapping soils and placing economic value upon them.

A serious competitor to the factorial approach arose at the end of the twentieth century with the strengthening of links between the soil sciences and scientific ecology. This sparked off a perspective now commonly referred to as 'the living soil approach' (Gobat et al., 2004). For many, this approach attests to a radical departure from the supposedly purely physicochemical 
orientation that previously prevailed. Pointing to the thousands of fungi and billions of bacteria that live in every gram of soil, some scientists argue that this new focus on the role of soil organisms amounts to nothing less than a 'renaissance' in the soil sciences (Hartemink and McBratney, 2008).

It was under the banner of the 'living soil' approach that an understanding of the predominant role of worms and other organisms in the growth of soil came to the fore. In fact, advocates of this approach - of whom there are now many - often proclaim as their precursor none other than Charles Darwin, who in 1881 had published an intriguing book on the creation of topsoil by earthworms (Darwin, 1881; Johnson, 2002). To them, the question of how soils grow and develop - or pedogenesis - is central. They argue that whereas Dokuchaev concentrated on factors of pedogenesis, Darwin's researches on bioturbation - the mixing of soils by organisms - centred rather on pedogenetic processes. For contrary to Dokuchaev's factorial approach, Darwin observed that organisms such as worms were central to the development of soils because through living in soils, they constantly transformed them.

What comes to the fore in the living soil perspective is thus an attention not only to soil organisms, but also to processes such as layering, the formation of aggregates, and the behaviour of soil colloids. For soil scientists, insisting on processes rather than factors of soil formation is far from being a side issue, as it bears on arguments for why the soil sciences are not reducible to other disciplines. For Churchman, the focus on soil processes is key to the soil sciences' renewed identity and originality, setting them apart as a distinct scientific field. Indeed, 'the possibility that these [processes] could be reduced to other sciences is dismissed because they can be explained more usefully at a larger size scale or by a more complex context than those belonging to more basic sciences such as physics or chemistry' (Churchman, 2010: 214). The approach to pedogenesis based on processes such as aggregation and bioturbation entails viewing soils as ecosystems in flux, permeated by many forms of life that do not just 
inhabit in it but altogether are the soil along with its other mineral and chemical components. Therefore, it erodes distinctions between the biotic and abiotic, between the animate and inanimate, vitalism and materialism.

In biology, vitalism has traditionally been founded on the idea that living beings are endowed with a 'vital principle', thus setting it up as the straw-man for a materialism that opposes any such principle. The two doctrines confronted each other in fierce debates throughout the twentieth century, and as Coole and Frost explain, hostilities were only resolved by 'distinguishing between the sort of mechanical, inorganic matter described by physicists and the evolving organic systems described by biologists' (Coole and Frost, 2010: 9). The 'living soil' approach to pedogenesis, however, rejects this distinction - just as do many of the 'new materialisms' in social theory to which Coole and Frost draw our attention. The question of how to deal and to live with living soils is, therefore, a good entry point for exploring opportunities for what Haraway calls a 'New New Synthesis' - one that avoids any strict separation between the domains of the social and the natural, or living and non-living, and that rather "proposes string figures tying together human and nonhuman ecologies, evolution, development, history, affects, performances, technologies, and more' (2016: 63).

\section{A soil scientist's notion of collaboration in making soil}

Besides resting on a heightened attention to soil organisms, and to processes of development rather than factors and states of reference, the renewed materialism at play within the soil sciences is also rooted in the idea that in order to understand the functioning of ecosystems, one has to engage in their processes of growth. Making becomes a means of knowing. Today, the old gardener's idea of teaming up with soil fauna in order to make fertile soil finds new echoes within the living soil approach. Indeed, over the last fifteen years or so, soil scientists have 
devoted much effort to 'constructing soil from scratch'. The idea is to recycle materials such as industrial, demolition or organic waste in order to rebuild artificial soil, the properties of which would be equivalent to those of natural topsoil.

As I have just explained in the case of fertile soils, the role of organisms such as earthworms is now understood to be crucial. In a benchmark treatise on The living soil, Gobat, Aragno, and Matthey speak of worms and microorganisms as the 'soil proletariat': 'Small in size, often passing unseen, they are however what "run the machine" of the soil' (2004: 129). This passage is notable for both its proletarian metaphor and its mechanistic vocabulary. In Europe, as a field of study, ecological engineering is not mainly about doing engineering in ways that are more respectful of the environment - as it is sometimes understood to be in the US. It rather takes advantage of certain ecosystemic functions in a design process that aims to distribute making between the human engineer and other organisms. Thus, it has come to define its practice through the principle that all organisms are 'ecosystem engineers', making this the central claim of its understanding of ecosystem design and construction (Jones et al., 1994). The process is viewed as a partnership - or a 'collaboration', in the phrasing of soil ecologist Patrick Lavelle (in Bouché 2014: 9, my trans.) - between the scientist and the organism-as-engineer. Together they are co-makers of the system.

In soil construction, earthworms are the main species co-opted as an ally in engineering projects. They are sometimes referred to as a kind of 'workforce' on which humans can rely to achieve the construction of a complex soil. ${ }^{1}$ One soil scientist describes them as 'a model of engineer-species $[\ldots]$ and we can affirm that along with the human engineers and architects that develop cities, the earthworm-engineer takes part in the harmonious development of the urban milieu' (Havlicek, 2016: 30, my trans.). Soil scientists sometimes refer to earthworms as 'the kings of soils.' They take them to be the main ecosystem engineers because they profoundly 
modify the physics and the chemistry of soils. As one of them put it to me, the intestines of worms can be regarded as 'an industry of soil construction'.

In order to construct soil, scientists start from a mix of granular materials ranging from coarse to fine - gravel, sand, crushed concrete, crushed green waste. This is what they would call somewhat arbitrarily - the 'initial conditions' of a soil. At this stage, particles of organic matter are largely distinct and separate from mineral ones. The mix is highly unstable. If it stays in this pulverised state, nutrients will be washed away with the rain, the air will slowly leak out and the whole mass will compact. Only thistles could grow in such a substrate.

Between 2013 and 2015, I carried out ethnographic fieldwork in two French research units that were attempting to grow soil experimentally. One of them was the Institute of Ecology and Environmental Sciences (IEES), in Paris, where Maha Deeb, then a Ph.D. student in Soil Ecology, and Manuel Blouin, her supervisor, were attempting to fabricate soil from green waste, backfill, and crushed concrete. Maha and Manu had created several soil mixes, which they tested on open sites and in the lab. At the IESS laboratory, Maha had placed samples of different soil mixes in small pots, along with various plants. She then introduced endogenetic worms of the species Aporrectodea caliginosa into the pots, in order to see how their presence would change the soil. ${ }^{2}$ Aporrectodea caliginosa is an indigenous worm in France, and it is known to have also adapted well to urban environments. Like its bigger cousin Lumbricus terrestris - the common nightcrawler - it eats and mixes mineral and organic matter. However, as an endogenetic worm, it remains under the surface, living and feeding within the uppermost 30 centimetres of soil, and mostly eats the soil itself - including mineral particles (Bouché 2014). There were about a hundred pots in Maha's experiment, kept in two 'phytotrons' - a sort of plant closet in which humidity, temperature and light intensity can be controlled so as to mimic specific climates or seasons. Maha visited the phytotron once a week to water the samples. At the beginning of her experiment, as we were routinely checking her samples and 
watering them to very precise amounts, she explained to me that 'at this stage, I don't have a soil, I only have mixes. I need to water them or they will collapse into a powder again'. But she added that by the time the experiment would be over, 'worms will have worked it, and there we will likely start to have something like a soil, with aggregates and a natural milieu for microfauna'. This colonisation by soil fauna gives rise to interesting ecological qualities.

For the soil scientists I have worked with, the sign that pedogenesis is taking place - of a soil beginning to emerge from this mix - is precisely aggregation, the chemical gathering of minerals and organic matter into larger compounds. Clay particles and organic matter are both charged negatively so they can't 'stick' by themselves. But thanks to the calciferous glands located in the walls of the earthworm's oesophagus, the chemical link of positive ions that they need, if they are to stick, can be provided in the process of their being digested by a worm. After passage through the worm's guts, these particles will form larger 'aggregates' that, for soil scientists, are the basis for the development of a soil that is durable in the long term, and sustainable without human intervention. For Maha, this is the principal promise of soil construction, and the difference between constructing soil and making compost.

Manu explains that 'soil structure is in fact aggregates plus void spaces. On this structure depend drainage, water retention, surface crusts, erosion... Whether nutrients will be washed away largely depends on it'. These aggregates allow the soil to carry life and plants durably, but they also exist because the soil is living, full of organisms which, in various ways, contribute to the processes of aggregation. Manu and Maha aren't interested in worms as organisms in the general sense, but rather in the functional domain they create by carrying on with their lives. As Manu summed it up in an interview,

If you are a worm, and you want to make an empty spot in a soil, you have to dig. By so doing, you create a vital space for other species because you 
remove material. Just think of microorganisms: for them, an aggregate is a continent. At some point, these aggregates simply identify with soil, and soil is there only because it is permanently rebuilt by aggregation.

An apprentice in the soil sciences has thus to develop the kind of attention that is needed to notice worm-formed aggregates. At the end of her experiments, Maha needed to find aggregates in her soil samples and to analyse them in order to know whether the mixes had 'turned into soil'. She explained how the clump of earth, once out of the pot, had to be delicately broken apart with the hands, and the plant roots then lightly shaken until only small pearl-sized aggregates were left sticking to them - forming 'threads' that, to me, looked like a necklace She then explained how to 'do a sieve with your fingers' to pull out the aggregates: 'you have to do this very smoothly, with much gentleness. You have to feel what the good touch is $[\ldots]$ aggregates are fragile and you don't want to break them. It's a method that asks the researcher to feel what she does'.

Sometimes, aggregates are the result of humidity and microorganisms alone, and Maha had to learn to tell the difference between these and aggregates formed by worm action. Her supervisor told us that 'you can tell the difference easily - the worm ones are much rounder', but it took us a long time to learn to pick up the distinction, whether visually or by pushing on the aggregates to sense their resistance. One trick is to use sieves of different sizes so that the eye can concentrate and notice aggregates more easily - almost as a gold prospector would do. Maha did all the sieving herself, repeating the exact same movements of her hands, up and down in circular motion, over and over again. She explained that you have to be gentle when sieving the aggregates, as they can erode easily. You have to find your own method and feel, while making sure to keep your movements even. Indeed, Maha added, 'because it's so dependent on the researcher's feel, some have criticised the method. But there is no other way, 
if you were to mechanise it you would break it all to dust. What's important is always to do the same movements. It will be reproducible thanks to some personal calibration'.

Unlike earlier research paradigms, which sporadically took an interest in worm castings for reasons such as that they 'contain a high percentage of water-soluble nutrients' (Barrett 1947, 25), aggregation-centred approaches have helped to change the definition of what a soil is. A soil, here, is neither a 'fertile substrate for plant growth', nor 'an organised succession of horizons', but the fold of a mix of particles and a process of digestion by a myriad of organisms. Lying at the boundary of the biotikos and a-biotikos, aggregates are typically irreducible to geology or biology. For some proponents of the living soil approach, aggregates are such a specific thing that they alone justify the existence of the soil sciences as an independent field, distinct from other sciences (Churchman, 2010). They are foundational to the living soil approach, showing that this perspective is not simply a takeover of the soil sciences by ecology, but truly an extension of both into new realms. As Marcel Bouché, a leading earthworm specialist puts it, aggregates are formed in the worm's habitation of the threshold between different realms: 'By decompacting the soil, creating pores and developing the surface of contacts between air, water and solids, earthworms make possible an intimate entanglement between the atmosphere, the hydrosphere, and the geosphere, upon which other organisms and roots can live' (Bouché, 2014: 13, my trans.).

I came to understand how aggregates can change the way one thinks of soils and looks at them, the day I went to a forest with Manu to collect worms for one of his experiments. We had to dig holes in several places of the forest in order to 'find good spots' where many worms would dwell. Manu explained that such good spots could be found 'not too close to the trees, but where you still find lots of the fallen leaves they eat'. Soil scientists have great respect for forest soils. In textbooks, they are often introduced as the canonical example of a well-developed soil. As we were digging in this rich forest soil, Manu took out a clump of dirt with his hands. He 
showed me how in this lump, roots and worm aggregates were enmeshed with one another, and commented with a happy look: 'when you see this, you really understand what soil is'.

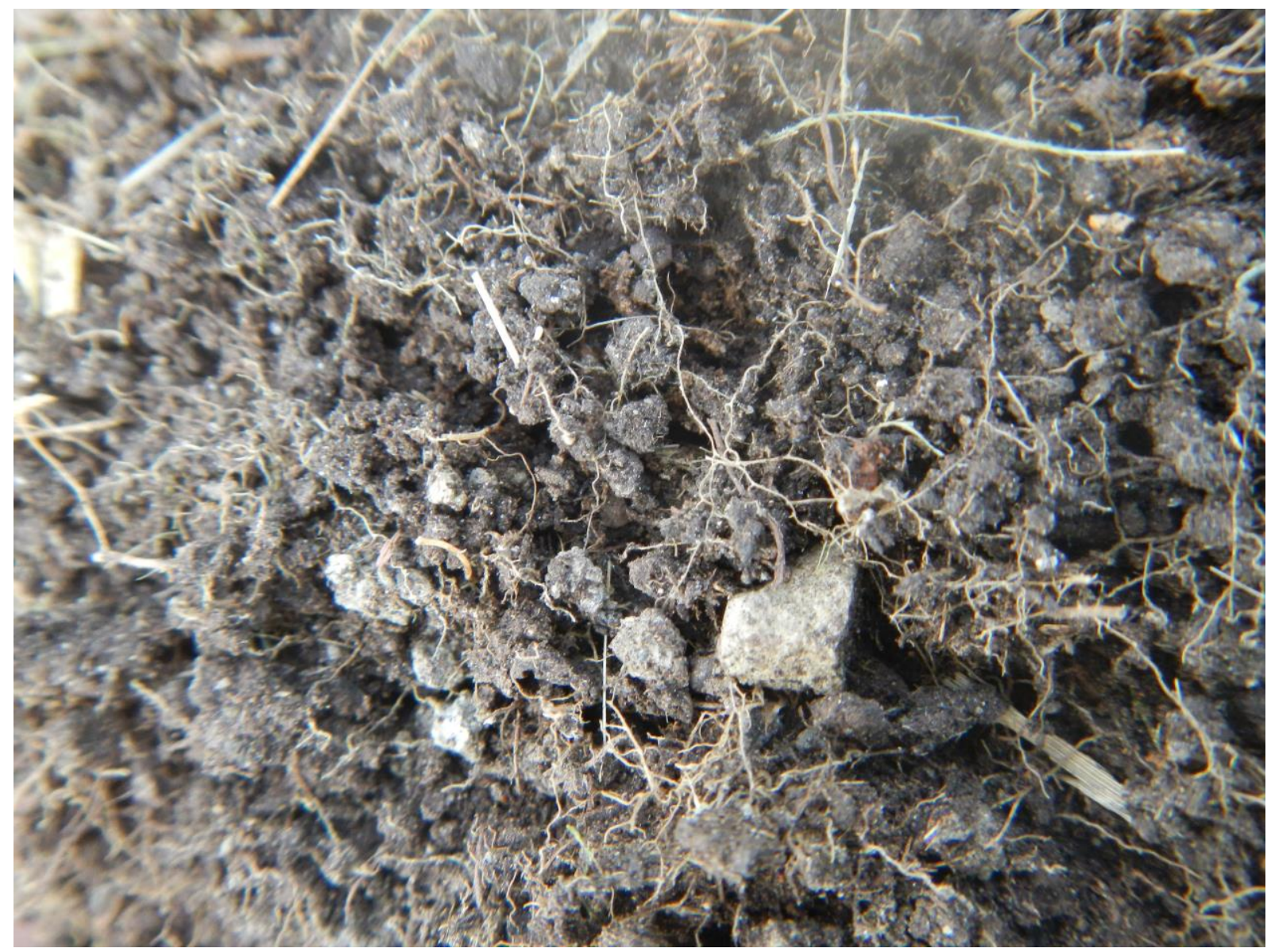

Figure 2: Manu's lump of forest soil (Photo by author)

In this single lump of soil, one could see minerals, organic matter, water, worms digging their way and digesting soil particles, organic matter degraded by microorganisms, plants pumping water, and their roots exploring every cavity of stones and pebbles. All of these are tangled in intra-active relatings, in which they are constantly transforming each other into something else. Their growth processes are not only things that happen to soil, together they are the soil. Maha was trying to isolate not 'the effect' of any one of these on the others, but what she called their 'interactive effects' (Deeb et al., 2017). As aggregates are the knots where this melding together 
can be felt, they index a practical understanding of soils as such a functioning compound. This is reminiscent of Donna Haraway's notion of sympoiesis, which describes processes in which life forms are always 'making-with', or 'worlding-with, in company' (Haraway, 2016: 58), rather than 'making themselves' (as in autopoiesis). Haraway uses this idea in conjunction with Lynn Margulis's work on symbiogenesis to show how evolution is always co-evolution. However, in contrast to Haraway's example of symbiogenesis, which concerns the co-evolution of organisms, the stories of becoming-with at play in pedogenesis also involve stones, silts, and other soil materials. I shall return to this.

\section{Worms worming: a boundary case for collaboration}

In order to address what is at stake in the kind of collaboration that goes on between worms and soil scientists in experiments of soil construction, we can start by asking ourselves what the worm does, what kind of work it carries out. A common response is to suppose that the organisms we think of as 'soil engineers' transform things rather passively. We could argue, as agronomists once did, that worms move and work in a perfectly mechanical way:

The earthworm is a digestive tube alone, stripped of all external incumbrance which might interfere with its life-function of digestion and equipped with just enough instinctive intelligence to carry out its feeding activities without too fine discrimination. Thus, everything which opposes itself to the blind attention of the earthworm becomes something to be devoured. (Barrett, 1947: 27)

Even though, as we shall see, soil scientists recognise that things are not as straightforward in practice, they do sometimes hold this view of the earthworm's action as unidirectional and 
relying on such unsurprising 'blind attention'. In this view, the role of scientists engaged in soil construction with worms would amount to the intentional manipulation of another organism's practices of niche-construction. This technicist understanding suggests that systematic knowledge of animal behaviour would allow scientists to manipulate it to serve human needs and that once their digestive activity is set towards the right human goal, worms can indeed be left alone to their task.

To manipulate the individuals of another species, however, is one thing; to collaborate with them quite another. Wherein, then, lies the difference? Are we to suppose that collaboration with non-human animals depends on the attribution to them of powers of intentionality, or planning capabilities, such as we routinely ascribe to our human selves? It is conceivable that animals such as non-human primates (Fuentes, 2012), elephants (Münster, 2016), reindeer (Stépanoff, 2012), or even cows (Porcher and Schmitt, 2012) possess cognitive skills sufficient for them to share some understanding with humans, and therefore that they can potentially be 'active participants in a number of different human-animal-technical social relations' (Candea, 2010: 243). But earthworms? These are creatures that dig, digest and transform matter as surely as humans breathe, but that certainly lack the higher consciousness and cognitive abilities of a kind that would facilitate their intentional collaboration. At best, they could be said to be working for humans, in so far as the latter could be said to manage the worms' blind ways of doing for their own profit. But worms could certainly not work with humans in this sense.

However, the idea that humans can only be said to collaborate with 'higher' animals, possessed of advanced cognitive capacities, has recently come in for criticism, particularly from those who, in refuting received assumptions regarding the human domination over nature, have called for a more symmetrical understanding of human-animal relations. Much of the debate has crystallised around the question of 'agency'. Arguably, the coupling of agency to intentionality - with the implication that there can be no action that is not premeditated - has served to elevate 
the human, and to demote animal doings to the status of merely reactive behaviours. But if agency is decoupled from intentionality, and ascribed instead to the networks of vital relations in which all living organisms, human and non-human, necessarily participate, then could not humans and worms, as co-actants within such a network, be equally said to collaborate? Earthworms are in fact one of the examples that Jane Bennett, a proponent of this view, discusses in her book Vibrant Matter (2010). Bennett argues for an extended understanding of life which transcends such binary categories such as organic versus inorganic, animate versus inanimate. Drawing on Darwin's book on worms and on Bruno Latour's Actor Network Theory (Latour, 2005), Bennett explains that the sort of agency that Darwin ascribed to earthworms is a 'small agency', which compounds with other such small agencies to produce big effects. Thus 'worms participate in heterogeneous assemblages in which agency has no single locus, no mastermind, but is distributed across a swarm of various and variegated vibrant materialities' (Bennett, 2010: 96). Rather than being a futile, passive creature, the worm can then be a crucial participant in the production of rich soil.

This focus on agency rather than intentionality makes it possible to do away with a humancentred account according to which worms' mechanical reactions are merely manipulated by intentional humans. Nevertheless, in my view, to regard worms as 'agents' pays insufficient respect to the renewed conception of life which the living soil approach offers. As I have already suggested, in this understanding of soils, worms and other organisms are inseparable from the world of active and changing materials they inhabit. When we think of what worms do to soil, the alternatives of seeing them either as 'active agents' or as 'passive reactants' activated by some other force, seem to present us with an impossible choice. ${ }^{3}$ The living soil approach, however, may help to take us beyond the active-passive dichotomy. In The Life of Lines (Ingold, 2015), Tim Ingold introduces the 'middle voice of the verb' which, besides the active and the passive voices, was common in ancient Indo-European languages. The middle voice suggests 
an undergoing that is also a doing, also active. Even though no longer current in modern English, we can find remnants in some grammatical forms. Ingold mentions one example of this: if we say that 'the wind is blowing', everybody knows that the wind is not accomplishing an act of blowing, but neither is the wind 'blown' by anyone or anything. Instead, Ingold observes 'the wind is its blowing' (2011: 317). In this, the wind exists in the blowing. In the middle voice, movement is the primordial condition.

Following from this, Ingold suggests that in order to render the processual becoming of things, in place of the nominal or pronominal subject, we would do better to use the grammatical form of the verb. Instead of nominal human beings, for example, he introduces the verb 'to human' (2015: 115). A human, then, is primarily its own doing, a 'humaning'. This also applies to what we commonly think of as 'objects', as exemplified in Edmund Carpenter's remark about Inuit sculpting: 'a carving, like a song, is not a thing, it is an action' (Carpenter, 1966: 212; c.f. Ingold, 2000: 126). Whereas agency pulls us back into a vision in which things are either 'doing something', or 'having something done to them' (undergoing), Ingold suggests a view in which humans and other beings are verbs, activities, carrying on. They are always and actively 'in the doing'.

For worms, to construct is in fact to excavate, to eat and to digest. This is how they 'engineer' things. As Bertoni (2013) suggests, worms' way of relating to the world through eating opens up a way to think of 'relations' in a completely different way from that to which we are accustomed. To address their mode of being, I follow Ingold's suggestion to start from the assumption that worms, just like any organism, are primarily sentient beings engaged in the task of carrying on their own lives. A worm, in this sense, can be thought of as a process: it is what it is thanks to the activity proper to it. It is, primarily, its worming. 


\section{A pedogenetic perspective}

Before moving on, we need to address a second assumption underlying conventional approaches to collaboration: that in collaboration, bodies work together upon matter - be it a field in the ploughing, pollen being turned to honey, or crushed materials becoming soil. Indeed, the approach favoured by soil scientists to characterise their collaboration with worms can be summed up in their characterisation as 'material mediators'. The soil powder, in its 'initial condition', is worked upon by both scientists and earthworms so that it becomes complex soil. ${ }^{4}$ This relies on the premise that both worms and humans imprint something upon matter, which awaits external action to take its form.

Now, while worms are primarily a transformative movement that can be characterised as a worming, they nonetheless participate in the larger generative currents of soil formation, as we have seen. We thus have to look at the larger current of things in which they are swept up: namely, soil. In the soil science literature, there is some ambiguity as to whether soils are the 'background' for worms, or their 'product'. As Marcel Bouché explains, worms 'reorganise the soil for their own comfort and efficacy. Meanwhile, they ingest their food, and through their digestion, render nutritive biogenic elements available for the plants that produce the organic matter they eat' 5 (Bouché, 2014: 214, my trans.). This relates to a wider difficulty in thinking of making and growing as two different things. The distinction between organisms that grow and artefacts that are made harks back to a longstanding opposition between nature and technique (Ingold, 2011). As Huneman notes, this antinomy was 'first rigorously formulated by Aristotle's Physics, for whom "natural" characterises the things having their own principle of growth, and "technical" are the things requiring an external principle of growth (e.g., engineers)' (Huneman, 2011: 78). More fundamentally, common notions of making and growing rest on the premise that things are formed through the application of a principle that can be either interior, such as genes, or exterior, such as the hand of the potter. Philosophers 
have described as hylomorphic those theories according to which things take shape through the conjunction of a substance ( Over the centuries, matter has come increasingly to be seen as a passive receptacle for a form actively presented to it. Conventional understandings of making and growing both imply an idea of form-taking as an operation in which a pre-existing form shapes raw matter; in other words, a formless nothing that only becomes a something through the creative effort of a maker.

This tension, however, can again be reduced by a processual operation: if we think of soils as things in the doing, as soiling. We can then suggest that their becoming is enmeshed with that of worming worms. This is to join with advocates of the living soil approach in their description of how soil grows: once a leaf falls from a tree and reaches the soil, they tell us, processes of decomposition start to take hold and alter the way it is organised. But in fact, nothing really 'disappears' in decomposition, and we could equally speak of 'recomposition'. As Adam Phillips (1999) notes, dissolution and decomposition are the basis for ecological continuity, including our own continuity with the world. In this, the death of organisms isn't the end of life, and decay is a productive force. Other previously living or non-living materials undergo dissolution through the action of bacteria. With the rain, these form juices that will penetrate the soil and feed the fungi that will make nutrients available for plants. Fungi, in turn, degrade lignin and aggregate materials, as they hold particles together with their filaments. They form networks that transport water and nutrients, live in symbiosis with many plants, and trap and eat nematodes. While the leaf becomes humus, rock is chemically altered by roots and weathered by rain and frost until it becomes sand, clay or silt. Biofilms and algae appear on the surfaces of minerals and, with their secretions, 'eat stone'. The soil materials react differently to water, and their cycles of expansion and compaction make room for air and water pockets which alter iron and other metals in different ways. Materials such as stones, water, air, and chemicals slowly combine into compounds of changing properties. They undergo a series of 
transformations in which food is turned into waste, particles into aggregates, liquids into solids, and vice versa. This, however, is not a unitary or closed cycle: it involves non-convergences and spontaneous re-organisation, as most soil ecologists would recognise. Thus soil materials grow too, they participate in transformative and generative fluxes. As suggested above, soils are soiling. However, soil scientists already have a word for this that obviates the need for a further neologism: the process in which soils grow from the imbrication of these fluxes of materials that are digested, decomposed and recomposed is what they call pedogenesis.

We may call here upon the idea of concrescence, on which Alfred North Whitehead elaborated at length in his search for a processual way of thinking (Debaise, 2017; Haraway, 2003: 6-10). ${ }^{6}$ To concresce is to grow with. It bears on the idea of collective formation, of association. It is a gathering in which several individual entities unite and form a new existence (thus Whitehead explains that organs are concrescences of cells, an army is a concrescence of soldiers, etc.). Each new entity is the concrescence of the entities that pre-exist it. It is the consolidation of an unprecedented relation between them, a hardened link that becomes a being in its own right. In pedogenesis - as we have outlined it here - separations between the worm and the soil (its associated milieu) becomes blurred. Once we take up a pedogenetic perspective, we understand that worms' actions cannot be reduced to an effect on passive matter. What the worm does instead is to move along with these materials in flux and re-arrange them by digestion. By doing so, it also constructs its own conditions for living, growing, and producing a larger community. Worms, in the pedogenetic view, are a site, a place where things happen, where what goes in is re-arranged, or, in the words of Nigel Thrift, 'an active and always incomplete incarnation of events, an actualization of times and spaces that uses the fluctuating conditions to assemble itself' (2007: 12n34).

The worm leaves a specific trace in this re-arrangement of its life-movement: an aggregate is both the trace and the result of worming. This challenges the distinction between the organism 
and its material background. Rather than being organisms in the soil, worms could be said to be folds of the soil. If one is to pose a view of organisms as unbounded entities, as 'places where things happen', then soils are more than a 'background' for organisms. Rather than thinking of 'the worm in the soil', we have to conceive of 'the worm as a site of pedogenesis'.

\section{Bundled up in concrescence}

Let us now return to Maha and her earthworms. How can we respond, in the framework we have outlined here, to the idea that the worm can be 'left alone' to its blind design? In our example, Maha is indeed far from turning a blind eye to what the worms are doing. To the contrary, much of her work consists in learning to notice worms' constructive movements.

In developing her understanding of soils, Maha observes the whole process of soil growth, touches the soil, looks for worms, and all of this requires caution and care for the worms. Scientists inclined towards a functional understanding of worms explain that worms are occasionally lazy. For instance, if one gives them what they really like, such as Lucerne hay, they don't need to work as much, so there will be little bioturbation. As Abrahamsson and Bertoni (2014) explain in an article about compost worms, without the tinkering of its keeper, the worms will leave, die, or simply not do anything. Whenever humans, scientists or not, intend to work with soils, they too engage in the activity of pedogenesis and follow the processual properties of materials and soil organisms. In this, the scientist's job is to find the right trick, what Latour, after French technologists, calls 'the art and manner to deploy technique' (2013: 209): to find the right watering, the right amount of clay at this or that depth so water will be retained. They become attuned to the preferences of earthworms and adapt the different soil mixes. They have to care for this 'demanding friend, who requires a subtle approach to be really understood' (Lavelle, 2014: 9, my trans.). 
That is why one has to develop and deploy an ongoing effort to attune one's caring with the activities of the worms. As Maria Puig de la Bellacasa (2017) demonstrates, caring and noticing bring each other about. In many ways, Maha's following of aggregates relies on an attentiveness to entanglements and processes of growth. It is an entry into a world in formation. The world of pedogenesis is not one of bounded objects set over against their surroundings, but one where everything is a more or less ephemeral concrescence of materials and organisms that mix and meld. It is a world in which forms don't 'exist' but rather 'occur' or 'take place'; a world where everything is a going-on, or 'a place where several goings-on become entwined' (Ingold, 2011: 315). Instead of reducing materials to matter endowed with agency, to take up a pedogenetic view is to recognise that they are themselves active. And as Ingold explains, 'in following these materials we take them as guides along a way of knowing' (2011: 313).

By way of the development of their attention through a sensuous engagement with soils, scientists who study them grow in skills and knowledge. As we have seen, they also redefine their disciplinary boundaries and build new spaces for knowing and experimenting. They are also 'made' in pedogenesis. The way in which Maha learns to notice her 'indefatigable collaborators', their bodies and their work, how she becomes attentive to entanglements and to processes of growth, depend on and inform her understanding of soil as a processual becoming. She became a 'living soil' scientist because of the way she learned to be affected and developed a 'feeling' for worms (Fox Keller, 1983). Maha and her worms, however, do not become subsumed into on overarching 'hybrid' form; to use an expression by Joanna Latimer, they rather change alongside (Latimer, 2013) each other, they undergo mutual extensions as they work together, while not necessarily sharing the same ends. What worms become with matters, and they do different things as they are conscripted into new projects: there would be little point for a classical pedologist of a classificatory persuasion to enrol worms in experimental projects of soil construction. Neither a classical pedologist nor 'his' or 'her' worms would participate in 
the same lines of growth as Maha and her aggregating worm-soil. In this process, which is full of detours, there unfolds a joint becoming in which new functions are brought about, a generative new way of being soil, or worm, or soil scientist - for they too are bundled up in the concrescent loops of pedogenesis.

\section{Conclusions}

Throughout this article, I have shown how practices of soil making help us think differently about more-than-human dependencies, questioning common notions of making and growing, activity and passivity, organic and inorganic, or life and non-life. I examined the emergence, in the soil sciences, of a 'living soil approach' centred on processes in which soil and organisms are intrinsically interwoven. I illustrated this by introducing the rich view of soil that unfolds from Maha and Manu's practices, as a mix of particles continually digested and worked upon by a myriad of organisms, lying at the boundary between geology and biology. Drawing links with the New Materialist literature (Coole and Frost, 2010), I suggested that this can help us reject distinctions between vital and material processes.

I then addressed ecological engineers' idea that in making soil, all organisms are fellow ecosystem engineers, and I asked what kind of work worms carry out in this shared making process. I reviewed the economic metaphors at play within the soil sciences, which consider worms to be a 'proletariat', a 'work-force' in 'an industry of soil construction'. I contrasted this to an alternative approach which grants worms agency - decoupling this notion from that of intentionality - in order to transcend dualisms such as or animate vs. inanimate and to do away with a human-centred account. I suggested, however, that to regard worms as agents pays insufficient respect to the renewed conception of life in soil ecology, in that it presents us with an impossible choice between activity and passivity. Drawing on the work of Tim Ingold (2015), I suggested that rather than thinking of soil beings either in the active or passive voice, 
we might call upon the 'middle voice', in which movement is the primordial condition. This leads me to think of worms as processes, as wormings.

I then suggested that if we are to take up this processual understanding, we must also address what happens to other soil materials, which are commonly referred to as being 'worked upon' by worms and engineers. This hylomorphic view, in which worms imprint something on passive matter, overlooks the ways in which worms participate in the larger current of things in which they are swept up. Again, I set about reducing this tension by regarding soils as a something in the doing, as soiling - or pedogenesis. Drawing on the notion of concrescence in order not to bifurcate what is animated from what is de-animated, I suggested that worms move along soil materials that are also growing in their interaction with organisms, and that bundle up to produce novel forms.

Only then could I return to the work of Maha, the soil ecologist, who surely cannot leave worms alone to their blind design activity, but has to work hard to keep them working. She has to pay attention and be advised by what worms are telling her - this is how she can know something about the soil. I ended by suggesting that because of this engagement in the soil's processes of growth, soil ecologists are also made in pedogenesis. I therefore want to conclude by suggesting that soil-human relations lure us towards new understandings of what it may mean to makewith, live-with, and collaborate in an animated world, rather than in one of passive materials. My aim has not been to propose a new general theory of relations, but rather to prise an opening through the specific angle that soi-making provides us with. This opening relates to that provided by new directions in theories of co-evolution (Haraway, 2016), at the same time as it provides different lures and stories to address worldly ecologies. Soils are not just a multispecies compound, they also stand at the threshold between biology and geology, the worlds of organisms and those of stones, air, and water. Thinking through soils, in the middlevoice of their making processes, brings us beyond dualisms between the animate and the 
inanimate, the biotic and abiotic. Pedogenesis means taking multispecies becomings into account, while also cutting across organic-inorganic divides. I view the healing of these ruptures as a crucial step towards making more liveable worlds amidst the ruins and toxic soils left by centuries of human exploitation. It is a step premised on noticing our collaborations and coemergence with the world's other inhabitants and its materials.

\section{References:}

Abrahamsson S and Bertoni F (2014) Compost Politics: Experimenting with Togetherness in Vermicomposting. Environmental Humanities, 4(1): 125-148.

Barrett, T J (1947) Harnessing the earthworm. A practical inquiry into soil-building, soilconditioning and plant nutrition through the action of earthworms, Boston MA: B. Humphries.

Bennett J (2010) Vibrant Matter: A Political Ecology of Things. Durham, NC: Duke University Press.

Bertoni F (2013) Soil and Worm: On Eating as Relating. Science as Culture, 22(1): 61-85.

Bouché M (2014) Des vers de terre et des hommes découvrir nos écosystèmes fonctionnant à l'énergie solaire. Paris: Actes Sud.

Candea M (2010) "I fell in love with Carlos the meerkat": Engagement and detachment in human-animal relations. American Ethnologist, 37(2): 241-258.

Carpenter E S (1966) Image making in Arctic Art. In: Kepes G (ed) Sign, Image, Symbol. New York, NY: G. Braziller, pp. 206-225. 
Churchman, J (2010) The philosophical status of soil science. Geoderma, 157(3): 214-221.

Coole D and Frost S (2010) Introducing the New Materialisms. In: Coole D and Frost S (eds) New Materialisms. Ontology, Agency, and Politics. Durham NC: Duke Uinersity Press, pp. 1-43.

Darwin C R (1881) The formation of vegetable mould, through the action of worms, with observations on their habits. London: John Murray.

Debaise D (2017) Nature as Event. The Lure of the Possible, Durham NC: Duke University Press.

Deeb M, Grimaldi M, Lerch T Z, Pando A, Podwojewski P and Blouin M (2016). Influence of Organic Matter Content on Hydro-Structural Properties of Constructed Technosols. Pedosphere, 26(4): 486-498.

Deeb M, Grimaldi M, Lerch T Z, Pando A, Gigon A and Blouin M (2016) Interactions between organisms and parent materials of a constructed Technosol shape its hydrostructural properties. SOIL, (2): 163-174.

Deeb M, Desjardins T, Podwojewski P, Pando A, Blouin M and Lerch T Z (2017) Interactive effects of compost, plants and earthworms on the aggregations of constructed Technosols. Geoderma, 305: 305-313.

Engel-Di Mauro S (2014) Ecology, Soils, and the Left: An Eco-Social Approach. Basingstoke: Palgrave Macmillan.

Fox Keller E (1983) A Feeling for the Organism: The Life and Work of Barbara McClintock. San Francisco, CA: W H Freeman and Co. 
Fuentes A (2012) Ethnoprimatology and the Anthropology of the Human-Primate Interface. Annual Review of Anthropology, 41: 101-117.

Gobat J-M, Aragno M and Matthe W (2004) The Living Soil: Fundamentals of Soil Science and Soil Biology. Enfield, NH; Plymouth: Science Publishers, Inc.

Haraway D J (2016) Staying with the Trouble: Making kin in the Chthulucene. Durham, NC: Duke University Press.

Haraway D J (2003) The companion species manifesto: dogs, people, and significant otherness. Chicago: Prickly Paradigm Press.

Hartemink A and McBratney A (2008) A soil science renaissance. Geoderma, 148(2): 123129.

Havlicek E (2016) Le sol urbain: surface inerte ou capital naturel? In P. Mantziaras \& P. Viganó, eds. Le sol des villes - ressource et projet. Geneva: MétisPresses, pp. 19-35.

Huneman P (2011) About the conceptual foundations of ecological engineering: Stability, individuality and values. Procedia Environmental Sciences, 9: 72-82.

Ingold T (2011) Being Alive. Essays on Movement, Knowledge and Description. New York, NY: Routledge.

Ingold T (2015) The life of lines. London: Routledge.

Ingold T (2000) The perception of the environment: essays on livelihood, dwelling and skill. London: Routledge.

Johnson D L (2002) Darwin would be proud: Bioturbation, dynamic denudation, and the power of theory in science. Geoarchaeology, 17(1): 7-40. 
Johnson D L and Schaetzl R J (2015) Differing views of soil and pedogenesis by two masters: Darwin and Dokuchaev. Geoderma, 237-238: 176-189.

Jones C G, Lawton J H and Shachak M (1994). Organisms as Ecosystem Engineers. Oikos, $69(3): 373-386$.

Latimer J (2013) Being Alongside: Rethinking Relations amongst Different Kinds. Theory, Culture ES Society, 30(7-8): 77-104.

Latour B (2013). An Inquiry Into Modes of Existence. An Anthropology of the Moderns. Cambridge MA: Harvard UP.

Latour, B (2005) Reassembling the Social - An Introduction to Actor-Network-Theory. Oxford: Oxford University Press.

Lavelle P, Lattaud C, Trigo D and Barois I (1995) Mutualism and biodiversity in soils. Plant and Soil, 170(1): 23-33.

Lavelle P (2014) Préface. In: Bouché M (ed) Des vers de terre et des hommes. Paris: Actes Sud, pp. 9-10.

Lyons K (2016) Decomposition as Life Politics: Soils, Selva, and Small Farmers under the Gun of the U.S.-Colombia War on Drugs. Cultural Anthropology, 31(1): 56-81.

Münster U (2016) Working for the Forest: The Ambivalent Intimacies of HumanElephant Collaboration in South Indian Wildlife Conservation. Ethnos, 81(3): 425447.

Phillips A (1999) Darwin's worms. On Life Stories and Death Stories. London: Faber.

Porcher J and Schmitt T (2012) Dairy Cows: Workers in the Shadows? Society and 
Animals, (20):39-6o.

Puig de la Bellacasa M (2014) Encountering Bioinfrastructure: Ecological Struggles and the Sciences of Soil. Social Epistemology, 28(1): 26-40.

Puig de la Bellacasa M (2017) Matters of care: speculative ethics in more than human worlds. Minneapolis, MN: University of Minnesota Press.

Rota E (2011) Early oligochaete science, from Aristotle to Francesco Redi. Archives of Natural History, 38(1): 136-163.

Ureta S (2016) Chemical Rubble: Historicizing Toxic Waste in a Former Mining Town in Northern Chile. Arcadia, 20. Available at https://doi.org/10.5282/rcc/7704

Stépanoff C (2012) Human-animal \&quot;joint commitment\&quot; in a reindeer herding system. HAU Journal of Ethnographic Theory, 2(2): 287-312.

Stewart A (2004) The Earth Moved. On the Remarkable Achievements of Earthworms. Chapel Hill, NC: Algonquin Books.

Thrift N (2007) Non-representational theory: Space, Politics, Affect. London: Routledge.

Tsing A L (2015) The Mushroom at the End of the World: On the Possibility of Life in Capitalist Ruins. Princeton NJ: Princeton University Press.

\footnotetext{
${ }^{1}$ Likening worms and soil fauna to a cheap workforce is not entirely new. Referring to the fertility of the Nile delta, André Voisin stated in 1960 that 'One often reads of the thousands of slaves that built the Pyramids for
} 
Pharaoh. In actual fact, these enormous edifices owe their existence in the main to the thousands of slaves inhabiting the sub-soil of Egypt' (Voisin, 1960 ; cited in Stewart, 2004: 107).

${ }^{2}$ Maha's specific research goals were to document the impact of microorganisms, plants, and worms on the constructed soil's properties and functioning, and to determine which plant and worm species were best at transforming urban waste materials into soil. She defended her thesis in 2016, and, along with her supervisor and colleagues, published her results in leading soil science journals (Deeb et al., 2016a; Deeb et al., 2016b; Deeb et al., 2017).

${ }^{3}$ Bennett prefers to describe worms as active rather than passive. But she can do this only by invoking a generalised 'vital force', in all materials, which does not do justice to the particular mode of being of worms. For her, worms are in the same basket with 'stem cells, electricity, food, trash, and metals' (Bennett, 2010: viii).

${ }^{4}$ This idea of chained causes and effects on soils notably comes through in what soil scientists call the 'sleeping beauty paradox' (Lavelle et al., 1995: 23), which refers to how the molecules contained in the worm's intestinal mucus 'activate' the microorganisms that have the 'capacity' to alter organic matter chemically.

${ }^{5}$ Marcel Bouché (2014) has addressed this specific problem by developing the concept of 'drilosphere', which has gained traction in the 'living soil' literature. The drilosphere encompasses the earthworm and the functional domain it creates and lives in. This concept, however, does not convey the processual sense that I wish to suggest here.

${ }^{6}$ As we have seen with Ingold $(2011 ; 2015)$ a processual understanding of the world starts with the idea that material things are immersed in currents of life. Similarly, for Whitehead, things, habits or organisms succeed in enduring, and their existence is always an achievement (Debaise, 2017: 67-71). This is also to recognise, with much of the contemporary STS, that scientific practices and forms of knowledge participate equally in the flows of the world - even when they are based on principles of 'detachment' (Candea, 2010).

\section{Biographical note:}

Germain Meulemans obtained his $\mathrm{PhD}$ in Anthropology from the Universities of Aberdeen and Liège in 2017. He is currently an IFRIS Postdoctoral Fellow at the Centre Alexandre Koyré (EHESS-CNRS-MNHN) in Paris. His research focuses on the 
significance of urban soils in the soil sciences, urban planning, and gardening activism, and on the development of experimental, collective ethnographies for addressing the politics of urban surfacing.

Centre Alexandre Koyré, 27 rue Damesme, 75013, Paris, France meulemans.germain@gmail.com

Acknowledgements: I would like to thank Caroline Gatt, Tim Ingold, Véronique Servais, Julien Dugnoille, as well as three anonymous reviewers, for their helpful and generous comments on earlier versions of this paper. 